\title{
Pemanfaatan Capsaicin Dari Cabai Dalam Menghadapi Fluktuasi Harga Cabai Di Pasaran
}

\author{
Bungaran Saing, Reni Masrida
}

Universitas Bhayangkara Jakarta Raya, Bungaran.saing@yahoo.com

\begin{abstract}
Abstrak
Cabai memiliki kandungan Capsaicin, Capsicin, Capsatin, Capsarubin, Caroten, Carotenoid. Capsaicin yang memberi rasa pedas pada cabai dapat diekstrak dengan pelarut tertentu akan menghasilkan oleoresin. Maka tujuan jangka panjang yang menjadi sasaran pengabdian masyarakat ini adalah mengatasi fluktuasi harga cabai yang tinggi (harga cabai rawit merah mempunyai CV sebesar 43,01\% dari tahun 2008-2012) dan mengurangi jumlah cabai yang diimport (import cabai tahun 2012: 26.838,7 ton). Kecamatan Taruma Jaya adalah daerah binaan Universitas Bhayangkara Jakarta Raya sebagai tempat dilaksanakan pelatihan ekstraksi capsaicin dari cabai sehingga masyarakat mendapatkan sumber mata pencaharian yang baru. Untuk mencapai tujuan tersebut dilakukan pelatihan dan pendampingan kepada masyarakat kecamatan Taruma Jaya untuk dapat mengekstraksi Capsaicin (pemberi rasa pedas) dari cabai dengan peralatan yang sederhana. Untuk itu Ekstraksi dilakukan pada tiga jenis cabai yaitu cabai merah, cabai keriting, dan cabai rawit merah dengan perbandingan bahan dengan pelarut etanol adalah 1:4. Ekstraksi dilakukan dengan metode maserasi dengan waktu 8 jam. Setelah pelatihan dilakukan pembimbingan dan pemantauan agar hasil oleoresin yang didapat selalu optimal yaitu sekitar $25 \%$ dari bahan baku sehingga diperoleh peningkatan penghasilan warga desa setempat dalam penjualan oleoresin industry rumahan mereka. Oleoresin yang diperoleh dapat disimpan dalam waktu lama sehingga dapat digunakan pada saat tidak musim cabai. Hal ini diharapkan menjadi solusi dalam menghadapi fluktuasi harga cabai di pasaran.
\end{abstract}

Kata Kunci: Capsaicin, Oleoresin, Ekstraksi, Fluktuasi harga, Pengabdian kepada Masyarakat (PKM)

\begin{abstract}
Carotenoids. Capsaicin which gives spicy flavor to chili can be extracted with certain solvents will produce oleoresin. So the long-term goal of community service is to overcome the high price fluctuation of chilli (the price of red pepper has a CV of 43.01\% from 2008-2012) and reduce the amount of imported chili (import chili in 2012: 26,838.7 ton). Taruma Jaya Subdistrict is a target area of Universitas Bhayangkara Jakarta Raya as a place for capsaicin extraction training from chili so that people get new sources of livelihood. To achieve these objectives, training and mentoring is done to Taruma Jaya sub-district community to extract Capsaicin (spicy flavoring) from chili with simple equipment. For that Extraction is done on three types of chilli that is red chili, curly pepper, and red chili with ratio of material with ethanol solvent is 1: 4 . The extraction was done by maseration method with time of 8 hours.
\end{abstract}


After the training is done guidance and monitoring so that the results obtained oleoresin always optimal that is about $25 \%$ of raw materials so as to obtain increased income of local villagers in the sale of oleoresin their home industry. Oleoresin obtained can be stored for a long time so it can be used at the time of no season chilli. This is expected to be a solution in the face of fluctuations in the price of chili on the market.

Keywords: Capsaicin, Oleoresin, Extraction, Price Fluctuation, Community Service (PKM)

\section{Pendahuluan}

Cabai adalah salah satu komoditas pangan utama disamping padi/beras, jagung, kedelai, gula, daging sapi, bawang dan kelapa sawit. Banyak jenis cabai yang tumbuh di Indonesia diantaranya cabai gendot, bird pepper, cabai ceplik, cabai domba/cabai rawit, cabai kathur, cabai jemprit, cabai putih, cabai merah, cabai hijau, pabrika/bell pepper, cabai keriting, cabai jepang, jalapeno, cabai jawa, cabai cherry dan yellow bahana pepper. Dari semua cabai yang tumbuh di Indonesia tersebut ada empat cabai yang paling banyak dikonsumsi yaitu cabai merah, cabai keriting, cabai hijau dan cabai rawit. Konsumsi cabai per Kapita per Tahun di Indonesia menurut jenisnya, 2008-2012 (kg) untuk cabai merah 1,550, cabai hijau 0,246 dan cabai rawit 1,329 (Pusdatin diolah dari Susenas BPS). Dan jika dibandingkan jumlah konsumsi dengan produksi cabai di Indonesia diperoleh surplus rata-rata sebesar 691,78 ton atau 49,16\% (diolah dari NBM, BKP, 2008-2012). Tetapi laju (\%/tahun) impor cabai di Indonesia cukup tinggi yaitu $111,18 \%$ seperti di tahun 2012 jumlah impor cabai sebesar 26.838,7 ton (Statistik Ekspor dan Statistik Impor 2008-2012 (BPS), diolah). Kemudian sebaran geografis produksi cabai di Indonesia masih terpusat di Jawa-Bali dan Sumatera seperti cabai merah tahun 2012, wilayah Jawa-Bali memproduksi $55,0 \%$, wilayah Sumatera 34,0\%. Ketersediaan cabai di Indonesia cukup melimpah pada saat musim panen, tetapi seringkali ditemukan kendala dalam pengangkutan maupun penyimpananya karena karakteristiknya yang mudah busuk. Hal-hal tersebut di ataslah yang menyebabkan fluktuasi harga yang tinggi (Cabai rawit merah mempunyai CV sebesar 43,01\% dari tahun 2008-2012) dan import cabai yang semakin tinggi (2012: 26.838,7 ton) pada saat bukan musimnya. Untuk mengatasi hal tersebut, oleoresin yang merupakan campuran minyak dan resin yang diperoleh dari hasil ekstraksi cabai akan memenuhi kebutuhan cabai tersebut pada saat bukan musimnya dan juga akan mengurangi fluktuasi harga yang tinggi.

Sejauh ini sudah terdapat beberapa teknologi untuk menambah umur simpan komoditas cabai. Salah satunya adalah dengan mengolah rempah segar menjadi serbuk. Dengan proses pengolahan tersebut, cabai segar dikeringkan hingga kadar air tertentu kemudian dihaluskan menjadi serbuk. Dengan dilakukan pengolahan ini maka penyimpanan cabai tidak akan memakan banyak tempat. Selain itu kadar air yang rendah akan menyebabkan mikroorganisme yang menyebabkan kerusakan pada cabai tidak tumbuh. Namun kelemahan sistem penyimpanan berupa serbuk adalah stabilitas kelembaban ruang penyimpanan yang dapat menyebabkan perubahan kadar air pada serbuk cabai dan menyebabkan tumbuhya mikroorganisme perusak. 
Capsaisin adalah zat utama yang mengakibatkan rasa pedas pada cabai. Capsaisin yang telah diekstraksi dari cabai akan diperoleh dalam bentuk oleoresin (Setyaningrum, dkk. 2013). Oleoresin adalah suatu ekstrak berbentuk gel atau pasta yang memiliki kandungan utama dari bahan yang diekstrak (Abubakar dkk 2005). Selain digunakan sebagai bahan pangan yaitu sebagai flavour, oleoresin capsaicin juga dapat dimanfaatkan dibidang farmasi dalam pembuatan berbagai obat-obatan (Voigt, R, 1994). Penggunaan oleoresin dapat mengurangi biaya transportasi karena volum per satuan berat akan berkurang dan penyimpanannya lebih mudah. Sebagai negara agraris yang memiliki jumlah produksi cabai tinggi, potensi pengolahan cabai menjadi oleoresin perlu ditindak lanjuti.

Untuk itu pengabdian masyarakat ini akan memberikan pelatihan kepada masyarakat pinggiran kabupaten Bekasi berupa teknik ekstraksi capsaicin (zat pedas) dari cabai tersebut dengan metode terbaik untuk dapat menghasilkan oleoresin cabai sesuai dengan hasil penelitian kami sebelumnya.

Kecamatan Taruma Jaya yang menjadi daerah binaan Universitas Bhayangkara Jakarta Raya menjadi pilihan pertama dalam pemberian pelatihan teknik ekstraksi capsaicin (zat pedas) dari cabai.

\section{Metode}

Kegiatan ini dilaksanakan di Kecamatan Taruma Jaya yang berlangsung selama 4 bulan dengan tahapan kegiatan seperti bagan 1 berikut ini.

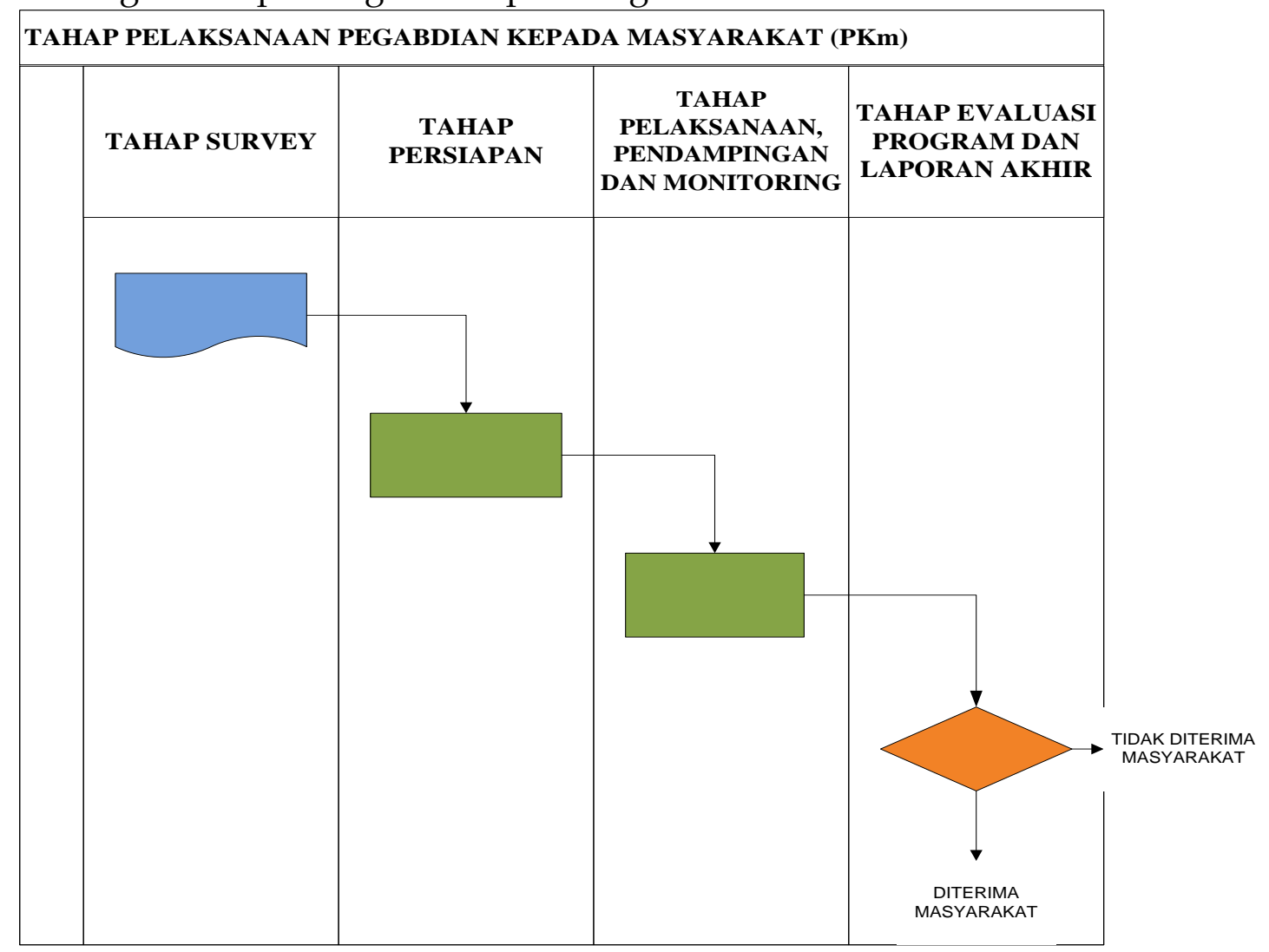

Gambar 1. Tahap kegiatan PKm Capsaicin 
Dalam pelaksanaan kegiatan ini tim PKm bekerjasama dengan BEM Jurusan Teknik Kimia-UBJ. Proses produksi oleoresin capsicum sebagaimana pada bagan 2.

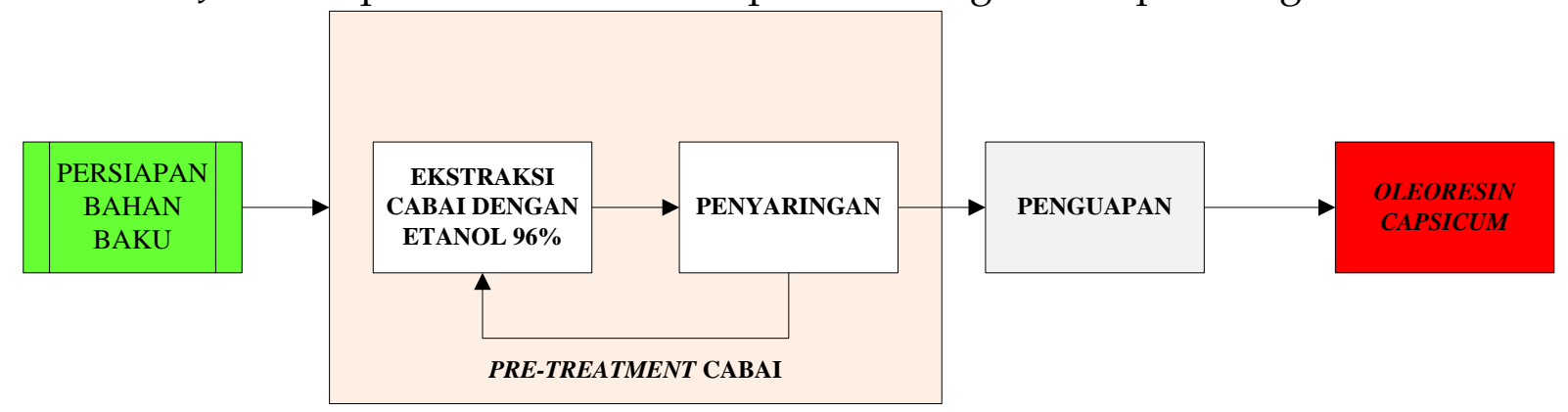

Gambar 2. Proses pembuatan Oleoresin Capsicum

Analisis yang dilakukan terhadap cabai dan hasil olahan dihitung secara kuantitatif dan kualitatif berupa:

A. Pengujian Bahan Baku

1. Kadar Air Cabai

$\%$ air $=\frac{\text { (bobot wadah }+ \text { bobot sampel awal })-(\text { bobot } \text { wadah }+ \text { sampel akhir })}{\text { bobot sampel }} \times 100 \%$

B. Pengujian Produk

1. Analisis Fisik, berupa warna, bentuk dan aroma.

2. Analisis tingkat kepedasan dengan metode: diuji oleh 5 orang panelis dengan ketentuan bahwa hasil dianggap sah jika nilai SHU (Scotville Heat Unit) pada 3 dari 5 orang panelis mengatakan ada rasa hangat ditenggorokan.

3. Uji Kelarutan, Uji pH dan \% rendemen.

$$
\begin{aligned}
& \text { Rendemen }(\% \mathrm{BK})=\frac{\text { berat oleoresin }(g)}{\text { berat bahan }(g)-(\text { KA } x \text { berat bahan })} \times 100 \% \\
& \text { Keterangan: } \\
& \text { BK }=\text { Berat Kering } \\
& \text { KA }=\text { Kadar Air }
\end{aligned}
$$

\section{Hasil Dan Pembahasan}

Pelaksanaan PKm diawali dengan pembekalan kepada masyarakat yang menjadi peserta/target/subjek, adapun inti dari materi yang diberikan adalah:

- Penyebab fluktuasi harga cabai di pasaran

- Alat dan bahan yang digunakan untuk mengekstraksi capsaicin dari cabai

- Metode pelaksanaan pelatihan

- Cara mengekstraksi capsaicin dari cabai

Berikut merupakan dokumentasi kegiatan pembekalan. 

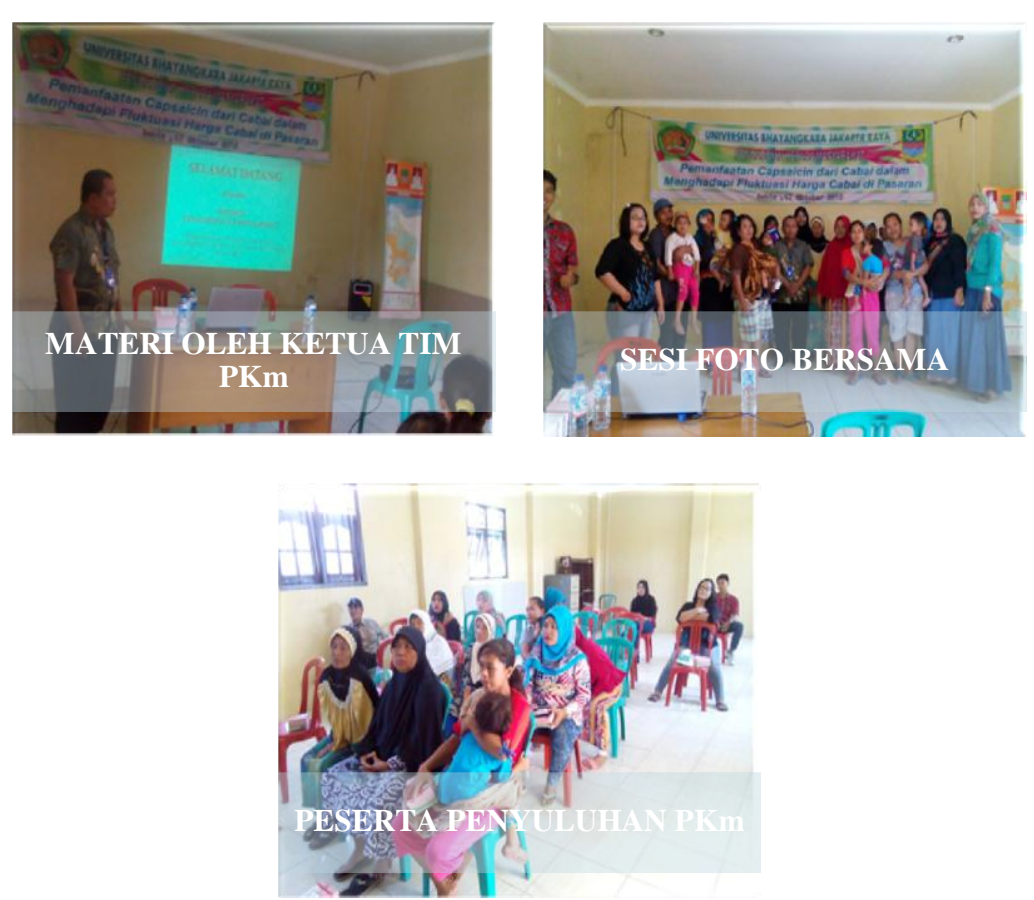

Gambar 3. Dokumentasi Pelaksanaan Penyuluhan

Tahap lanjutan dari pembekalan adalah implementasi lapangan yang melibatkan warga secara langsung, sebagaimana dokumentasi berikut ini.
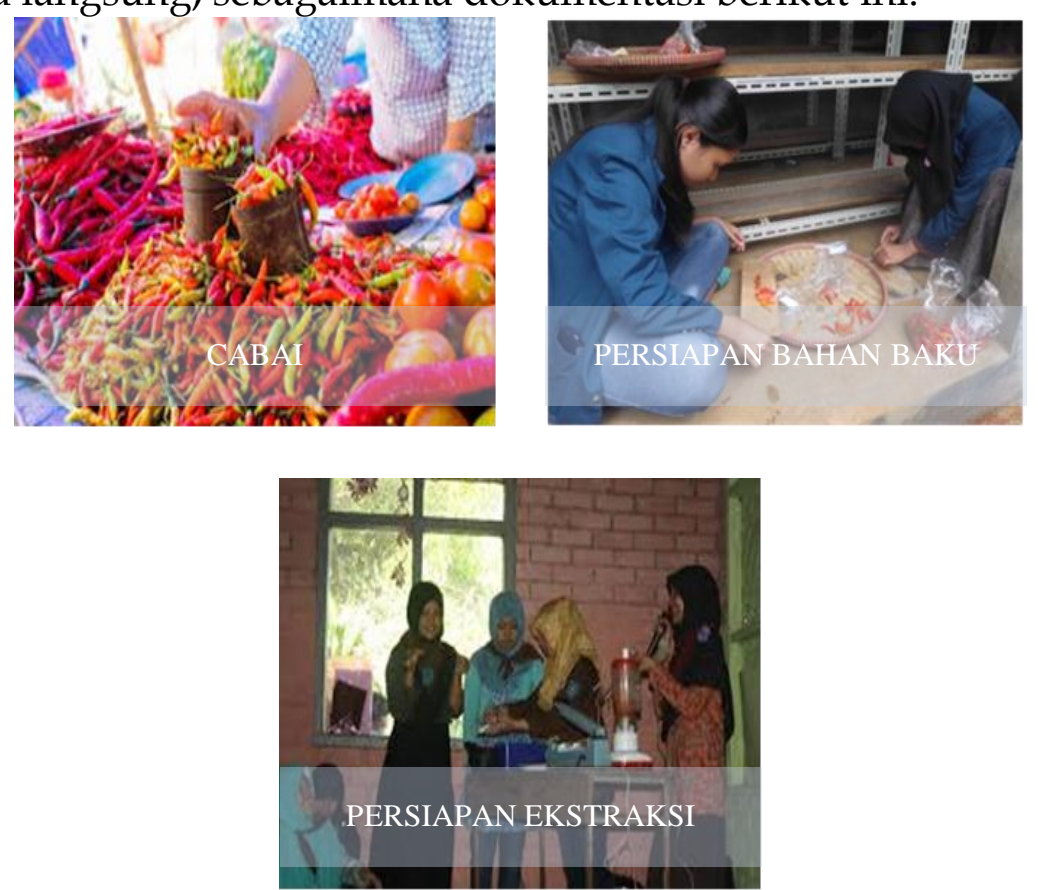

Gambar 4. Dokumentasi Pelaksanaan Ekstraksi Cabai

Indikator keberhasilan kegiatan PKm secara normatif adalah jika rencana kegiatan mencapai hasil yang sama dengan pelaksanaan di lapangan maka dapat dikatakan sesuai dengan yang diharapkan atau berhasil. Berikut merupakan beberapa indikator capaian penyelenggaraan kegiatan PKm yaitu: 


\section{a. Materi pelatihan}

Materi pelatihan direncanakan sesuai dengan materi pelatihan yang telah disiapkan oleh nara sumber, dan hasil ini sesuai dengan diberikan saat praktek di lapangan. Pemberian materi disampaikan dalam bentuk powerpoint dan hard copy materi pelatihan yang diberikan kepada setiap peserta.

b. Jumlah peserta pelatihan

Jumlah peserta yang semula direncanakan sekitar 15 orang, tetapi dalam kenyataannya pelatihan diikuti oleh 28 orang, berarti dari sisi jumlah peserta tercapai keberhasilan karena banyaknya peminat terhadap pelatihan ini.

c. Perhatian peserta

Intensitas perhatian dan kehadiran dari awal acara sampai berakhir acara kegiatan, menunjukkan mereka telah mengikuti acara kegiatan dari awal acara sampai acara selesai denan baik. Hal ini juga menunjukkan suatu keberhasilan kegiatan.

d. Bahan pelatihan

Bahan pelatihan berupa alat, bahan, makan dan minum serta snack selama pelatihan berlangsung disediakan oleh tim PKm.

\section{Simpulan Dan Rekomendasi}

Berdasarkan hasil pelaksanaan kegiatan PKM yang telah dilakukan dapat diambil kesimpulan sebagai berikut:

1. Telah dilakukan pelatihan mengenai cara mengekstraksi capsaicin dari cabai sehingga diperoleh oleoresin capsaicin yang lebih tahan lama dalam penyimpanan sehingga dapat dikonsumsi pada saat tidak musim panen cabai.

2. Peserta memperoleh pendapatan baru berupa produksi oleoresin capsaicin dari industri rumahan.

Berdasarkan pelatihan PKM yang telah dilakukan maka saran yang direkomendasikan adalah:

1. Keterlibatan pemerintah Desa setempat untuk senantiasa memantau aktifitas produksi oleoresin capsaicin secara berkelanjutan sehingga manfaat PKm ini terlihat bagi kemakmuran dan kesejahteraan desa tersebut.

2. Diperlukan pelatihan-pelatihan lainnya yang mendukung aktifitas masyarakat desa sehingga percepatan perbaikan ekonomi dan pembangunan desa dapat berpengaruh bagi kesejahteraan masyarakat.

\section{Acknowledgements}

Kami selaku tim pelaksana kegiatan PKm mengucapkan terima kasih yang tak terhingga atas terbentuknya kemitraan dan kerjasama dengan pihak Kecamatan Taruma Jaya Kabupaten Bekasi Provinsi Jawa Barat berikut warga, serta BEM Jurusan Teknik Kimia yang sudah berpartisipasi sehingga PKm ini dapat terlaksana dengan baik. Terima kasih kami untuk Lembaga Penelitian UBJ atas pendanaan yang diberikan. 


\section{Daftar Pustaka}

Abubakar, Edy Mulyono, Yulianingsih. 2005. Prospek Oleoresin dan Penggunaannya di Indonesia. Balai Besar Litbang Pascapanen Pertanian, Bogor

Badan Pusat Statistik. Beberapa tahun. Pengeluaran Penduduk Indonesia, BPS. Jakarta

Badan Pusat Statistk. Beberapa tahun. Statistik Indonesia, BPS. Jakarta.

Direktorat Pangan dan Pertanian. 2013. Rencana Pembangunan Jangka Menengah Nasional (RPJMN) Bidang Pangan dan Pertanian 2015 - 2019, Bappenas. Jakarta

Direktorat Pemasaran Domestik, Ditjen PPHP Kementan 2013

Pusat Data dan Sistem Informasi Pertanian, Kementerian Pertanian bersumber dari hasil Survei Sosial Ekonomi Nasional (SUSENAS) BPS,

Neraca Bahan Makanan (NBM) - Badan Ketahanan Pangan, website FAO (Food Agriculture Organization) dan website USDA (United States Departement of Agriculture)

Setyaningrum, Laras Wahyu, 2013. Ekstraksi Oleoresin Capsaicin dari Cabai Merah, Cabai Keriting, dan Cabai Rawit. IPB. Bogor.

Statistik Ekspor dan Statistik Impor 2008-2012, BPS. Jakarta

Voigt, R, 1994, Buku Pelajaran Teknologi Farmasi edisi 5, Gadjah Mada University Press, Yogyakarta, hal 17 